\title{
CORRESPONDENCE
}

\section{THE EDGE OF THE ANTARCTIC CONTINENTAL SHELF}

I have just read Phillip Law's letter in the Polar Record, Vol 10, No 67, 1960, p 415, on the subject of the delineation of the edge of the Antarctic continental shelf and, although I agree with his desire that this should be delineated as accurately as possible, I cannot agree that the sea bed of the continental platform is "fairly level". On the contrary, precise charts on a larger scale show an irregular relief similar to that on the Norwegian and Greenland coasts. Obviously more investigations are required-for instance, it would be interesting to know whether the sea bed is composed of firm rock or morainic gravel or sand. I may refer to several papers of my own on the subject, in particular "The problem of coastal genesis with special reference to the 'strandflat', the 'banks' or 'grounds' and the 'deep channels' of the Norwegian and Greenland coasts". Journal of Geology, Vol 70, No 5, 1962. I am convinced that the same geomorphological forms exist, and that the continental border round Antarctica developed in the same way as the coast of Norway.

WILHELM EVERS

\section{DEPARTMENT OF GEOGRAPHY \\ TECHNICAL UNIVERSITY \\ HANNOVER \\ 22 September 1964}

Dr Law replies:

I am glad to receive the support of Professor Evers for my suggestion for delineating the edge of the Antarctic Continental Shelf. I am quite prepared to withdraw the description "fairly level" which I used. In many places, where high points have been scraped off by icebergs and hollows have been filled by deposition of morainic material, our echo-sounder records show that over large areas the surface of the shelf is remarkably flat. Elsewhere, I should be interested, as Professor Evers is, to obtain more information about the geomorphology of the ocean bottom around the Antarctic coastline, for its value in solving the problem of coastal genesis in unquestionable.

PHILLIP LAW

ANTARCTIC DIVISION

DEPARTMENT OF EXTERNAL AFFAIRS

MELBOURNE

20 November 1964 